\section{SAP-06 少数性生物学の展望}

Prospect of minority biology

Takeharu Nagai (ISIR, Osaka Univ.)

Cooperative function/behavior in biological nanosystems consisting of small number of molecular elements is one of the most important aspects in biological phenomena. Although so many studies in terms of biochemistry and single molecule biology, which deal with Avogadro's number of molecules and single molecule, respectively, have been reported, there is almost no report showing elementary process of cooperative function/behavior among small number of molecules in living cells (from BSJ2012 Symposium abstract written by Nagai and Ishijima,). In this symposium, I will overview recent technological progress which could be applied and/or useful for investigating the small number problem, and also show several biological phenomena that should be suitable to approach it.

\section{SBP-03 コレラ菌の鉄獲得機構}

Heme-iron uptake proteins from Vibrio cholerae

Takeshi Uchida (Grad. Sch. Sci., Hokkaido Univ.)

Iron is an essential element for bacteria to survive. To obtain this element, bacterial pathogens utilizes heme from hemoglobin as an iron source. Recently, we found in Vibrio cholerae two enzymes, which liberate iron from heme in a different manner. VCA0907 (HutZ) is a heme degradation enzyme, which catalyses the $\mathrm{O}_{2}$-dependent degradation of heme, while VC2145, whose crystal structure shows close similarity to those of a family of dye-decolorizing peroxidases, removes iron without breaking heme under anaerobic condition. The presence of two different kinds of enzymes to obtain iron from heme suggests that $V$. cholerae can adapt to different $\mathrm{O}_{2}$-concentration environment.

\section{SBP-01 構造細胞生物学とは Structural cell biology}

Toshio Hakoshima (Grad. Sch. Biol. Sci., Nara Inst. Sci. Technol.)

At key steps involved in cell signaling pathways, multiple proteins form molecular complexes through complexed intermolecular interactions. Our primary goal of structural cell biology is to determine the threedimensional structure of these complexes for taking a snapshot of proteins in the act of performing their functions. The obtained structural knowledge enables us to establish a scientific field that strictly defines the origins of the specificity of these interactions and to reveal the mechanisms by which proteins regulate their molecular functions.

\section{SBP-02 C 型レクチン受容体 Mincle の糖脂質認識機構}

Structural basis for glycolipid recognition mechanism by $\mathrm{C}$ type lectin like receptor, Mincle

Atsushi Furukawa ${ }^{1}$, Jun Kamishikiryo ${ }^{2}$, Toyoyuki Ose ${ }^{1}$, Sho Yamasaki ${ }^{3}$, Katsumi Maenaka ${ }^{1}\left({ }^{1} \mathrm{Grad}\right.$. Sch. of Pharm., Univ. of Hokkaido, ${ }^{2}$ Sch. of Pharm., Univ. of Fukuyama, ${ }^{3}$ Med. Inst. of Bioreg., Univ. of Kyushu)

C-type lectin like receptors (CLRs) express on the surface of immune cells and recognize pathogen associated molecular patterns (PAMPs). Mincle (Macrophage inducible C-type lectin), which is one of CLRs, directly recognizes TDM (Trehalose 6,6-dimycolate), unique glycolipid on the cell surface in Mycobacterium species. TDM is well known as an adjuvant, thus the Mincle-TDM interaction plays an important role in activation of immune cells. Previous reports indicated that Mincle recognizes both sugar and lipid of TDM. However, the recognition mechanism of TDM by Mincle had not been understood. Here, we present the crystal structure of Mincle, and compare it with other C-type lectins to reveal the molecular mechanisms of substrate specificity.
2SBP-04 糖タンパク質品質管理システムにおける糖鎖修飾メカニズム の構造基盤

Structural basis for the glycan-processing mechanisms in glycoprotein quality control system

Tadashi Satoh ${ }^{1,2}$, Koichi Kato ${ }^{1,3}\left({ }^{1}\right.$ Grad. Sch. Pharm. Sci., Nagoya City Univ., ${ }^{2}$ JST, PRESTO, ${ }^{3}$ Okazaki Inst. Integ. Biosci.)

Glycans act as signals for quality control of glycoproteins, ensuring their appropriate folding and trafficking in cells. Glucosidase II catalyzes twostep glucose-trimming, while folding sensor enzyme UDP-glucose glycoprotein glycosyltransferase (UGGT) transfers glucose to incompletely folded glycoproteins, thereby allowing them to access with endoplasmic reticulum (ER) chaperone complex. To unveil working mechanism of the glycoprotein-quality control system, we attempt to elucidate the 3D structures of these glycan-processing enzymes. Here, we will present our latest results including crystal structures of catalytic domain of glucosidase II and folding sensor domain of UGGT. Our findings provide structural basis for ER glycan-processing mechanisms at atomic level.

2SBP-05 G タンパク質共役型内向き整流性カリウムイオンチャネル 1(GIRK1)の G タンパク質による機能調節の構造基盤 Structural Basis for Regulation of G Protein-activated Inwardly Rectifying Potassium Channel 1 (GIRK1) by G Proteins

Masanori Osawa ${ }^{1}$, Yoko Mase ${ }^{1}$, Mariko Yokoagawa ${ }^{1,2}$, Koh Takeuchi $^{3}$, Ichio Shimada ${ }^{1}$ ( ${ }^{1}$ Grad. Sch. Pharm. Sci, The Univ. of Tokyo, ${ }^{2}$ JBic, ${ }^{3}$ Molprof, AIST) G protein-gated inwardly rectifying potassium channel (GIRK) plays a crucial role in regulating heart rate and neuronal excitability. The gating of GIRK is regulated by the association and dissociation of $G$ protein $\beta \gamma$ subunits $(\mathrm{G} \beta \gamma)$, which are released from pertussis toxin-sensitive $\mathrm{G}$ protein $\alpha$ subunit $(\mathrm{G} \alpha \mathrm{i} / \mathrm{o})$ upon GPCR activation in vivo. Gai/o also interacts directly with GIRK, increasing the signaling efficiency and modulating the channel activity. Here, we performed NMR analyses of the interaction of the cytoplasmic region of GIRK1 (GIRKCP) with G $\beta \gamma$ and Gai3 in the GTP-bound state, respectively. Our NMR results enabled to build a docking model of $\mathrm{G} \alpha, \mathrm{G} \beta \gamma$, and GIRK, providing structural basis for the regulation of the GIRK gating by $\mathrm{G}$ proteins. 